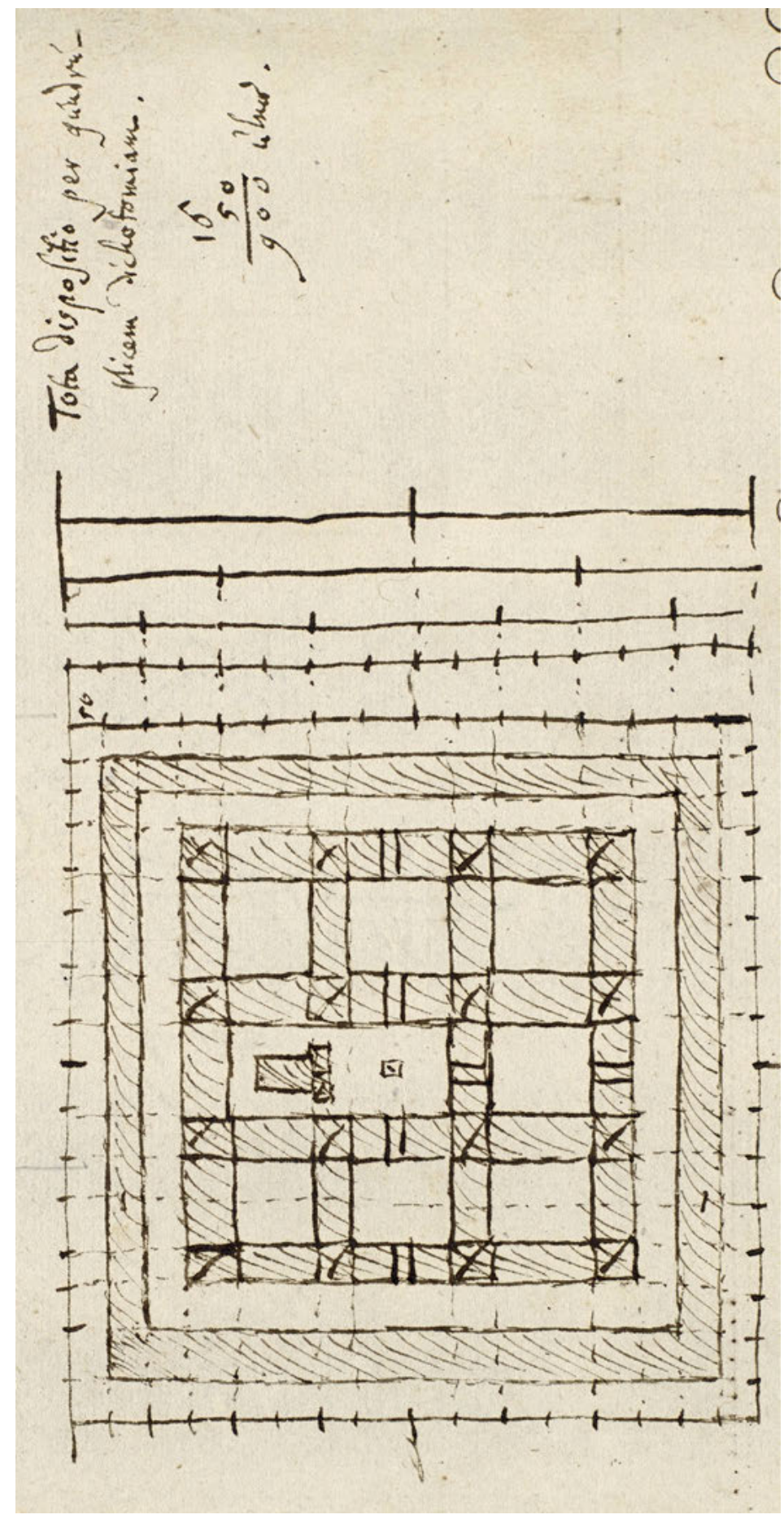

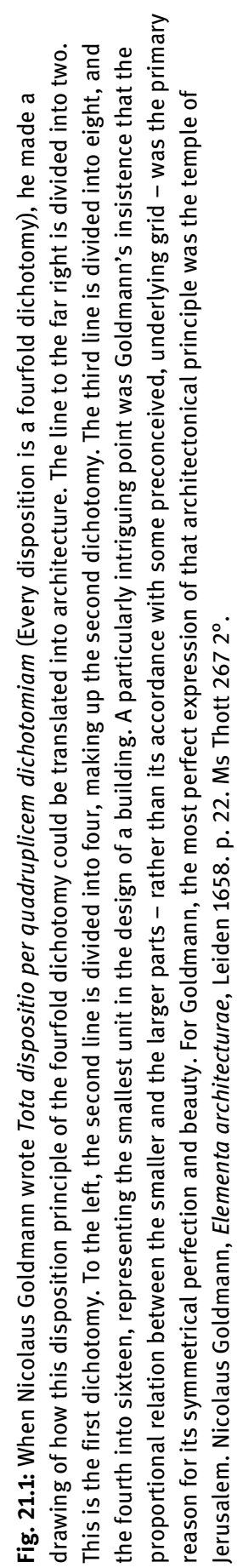

Ә Open Access. (c) 2021 Joar Haga, published by De Gruyter. (c) BY-NC-ND This work is licensed under the Creative Commons Attribution-NonCommercial-NoDerivatives 4.0 International License. 


\section{Consecrating the New Jerusalem in Tranquebar}

This article considers what the heavenly city may have meant for the first Lutheran missionary endeavour. When the Danish king sent German Pietists from Halle as missionaries to Tranquebar, to the king's trade station in India, the missionaries named their mission church "New Jerusalem." The choice of name is intriguing because it points to an ambivalence that characterized the conception of the enterprise. By presenting some material from the missionaries, I ask in what sense their activity among the Tamil was understood as taking part in the realization of the promised city, the New Jerusalem. Although the Pietists were reluctant to interpret worldly structures as identical with the heavenly reality, their millennial outlook harboured hopes for a concrete realization of the kingdom of God. This ambivalence points to a major tension within the Jerusalem code itself: to what extent did the eternal city "up there" extend into the temporal spheres "down here"?

Inspired by mercantilism, Denmark-Norway chartered the Danish East India Company in 1616 under Christian IV (r. 1588-1648), and became a colonial power by the possession of Tranquebar. When Frederick IV (r. 1699-1730) ninety years later sent missionaries to Tranquebar, they represented a new export article from Scandinavia, namely the Pietist attempt to include the people on far shores abroad in the worldwide church. Bartholomeus Ziegenbalg (1682-1719) and Heinrich Plütschau (1676-1752), his colleague, were spiritual disciples of August Herman Francke (1663-1727) in Halle, and were recruited from Germany.

On 11 October 1718 Ziegenbalg held his inauguration sermon for the newly built church, New Jerusalem, in Tranquebar. It was the birthday of the Danish king Frederick IV and the event marked the beginning of a new aeon. ${ }^{1}$ The new church was partly designed by the German architect Leonard Christoph Sturm, a pioneering architect with a profound interest in the representations of New Jerusalem on

1 Jeyaraj claimed that the church is viewed as the mother of all Protestant churches in India. Daniel Jeyaraj, Bartholomäus Ziegenbalg: The Father of Modern Protestant Mission. An Indian Assessment (New Dehli: Society for Promoting Christian Knowledge, 2006), 116.

Joar Haga, Associate Professor, VID Specialized University, Stavanger, Norway; former Post Doctoral Fellow at MF Norwegian School of Theology, Religion and Society, Oslo, Norway 
earth. ${ }^{2}$ It took the place of another church, which Ziegenbalg and his congregation had left after twelve years, which also bore the name "New Jerusalem." The name New Jerusalem, the divine city of the Book of Revelation, marked the difference to the old Zion, the name of the old church at Tranquebar. This article addresses what the name of the heavenly city meant to the missionary endeavour, and in what sense was the missionary activity among the Tamil understood to be a part of the realization of the promised city, the New Jerusalem.

In order to answer this question, I will turn to how the Pietist movement understood New Jerusalem. There was an ambivalent attitude towards the concrete realization of Jerusalem within the Pietist tradition itself; the Pietists could accentuate both a New Jerusalem that was already at hand - at least in its inception - and they could accentuate a not yet. On the one hand the teacher of the missionaries, August Herman Francke, underlined that his great project of a "universal seminar" was not a rem publicam platonicam, existing merely in the imagination. ${ }^{3}$ His large venture, the famous orphanage, was not a utopia - it had a real place in Halle as already a beginning, a "pledge," for the great Reformation of church and society. ${ }^{4}$ On the other hand, the Pietists strongly emphasized the antithesis between spirit and matter. ${ }^{5}$ This tension made an identification of the kingdom of God with concrete worldly or human structures difficult for the Pietists. ${ }^{6}$ New Jerusalem could simply not be realized, partly because it was embedded in human structures and as such was bound to "the works of human hands." In 1718, when the second New Jerusalem church was

2 Cf. Claus Bernet, "Sturm, Leonhard Christoph," in Biographisch-Bibliographisches Kirchenlexikon (Nordhausen: Verlag Traugott Bautz, 2001).

3 Wolfgang Breul, "August Hermann Franckes Konzept einer Generalreform," in Geschichtsbewusstsein und Zukunftserwartung, eds. Wolfgang Breul and Jan Carsten Schnurr (Göttingen: Vandenhoeck \& Ruprecht, 2013), 78. Cf. the verdict of Eric Gritsch: "Halle had become to Francke a new Jerusalem." Eric W. Gritsch, A History of Lutheranism (Minneapolis: Fortress Press, 2002), 148.

4 "Das Hallesche Waisenhaus wurde zum Synonym für die konkrete Errichtung des Reiches Gottes als Angeld für eine Erneuerung von Kirche und Gesellschaft." Peter Schicketanz et al., Der Pietismus von 1675 bis 1800, vol. 1 (Berlin: Evangelische Verlagsanstalt, 2001), 88.

5 The sceptical attitude towards the external reality is found everywhere. Francke wrote, for example, in his 30 Rules for a Good Conscience, that the company of others "is a chance to sin" (Rule 1). One should take care so that "nobody disturbs your inner peace" (Rule 2). The external contact with the godless is not possible to avoid, but it is important to enter into contact with them only if they are in need or if there is "hope for betterment" (Rule 12). Particularly telling is Rule 24, where laughter is not entirely condemned: one can be delighted over divine things, in an internal delight. A. H. Francke, Dreissig Regeln, zu Bewahrung des Gewissens und guter Ordnung in Gesellschaft (Nürnberg: Raw'schen Buchandlung, 1832). Cf. Wolfgang Martens, "Officina Diaboli. Das Theater im Visier des Halleschen Pietismus,” in Zentren der Aufklärung 1.Halle. Aufklärung und Pietismus, ed. Hinske Norbert (Heidelberg: Lambert Schneider, 1989), 189.

6 Francke's modern biographer, Friedrich de Boor, sees Francke's historical significance exactly in his ability to connect a spiritualistic waiting for the sign of the times and an activist labour in God's work. Friedrich de Boor, “Francke, August Hermann (1663-1727),” TRE 11,315-16. 
consecrated, Ziegenbalg underlined the words from Acts 7, that God "dwelleth not in temples made with hands." There was in the embedded Pietist anxiety about the world as a place of temptation ${ }^{7}$ a concern for the deceptive power of the external. This was not because of its inherently evil essence but because of its possibility to destroy the (good) will.

This ambivalence between already and not yet is the point of departure for this chapter. It asks whether the New Jerusalem church in Tranquebar was a signal light of a possible realization of the heavenly city. Did the missionaries affirm the assumption that the New Jerusalem church - as the epitome of missionary effort represented the Kingdom of God breaking into the world? Or were they rather reluctant to make such claims, placing its realization in the afterlife?

\section{The Background of Tranquebar as a Mission Station}

In his standard account of mission history, Kenneth Scott Latourette remarked that King Frederick IV of Denmark "had for some reason come to feel an obligation to see that missionaries were sent to the non-Christians touched by Danish colonies and trade." 8 In 1705, Frederick IV had sent two Lutheran missionaries to Tranquebar with the order to "teach the heathens who live in our territory and in the neighbouring regions the holy doctrine as it is given in God's word, Daniel Cyranka in the symbolic books and in the Augsburg confession and to bring them the message of salvation [. . .]."9

The king's interest in mission activity has been quite a riddle for historians to explain. As an absolute king with mistresses and polygamous relations, he did not seem to be particularly close to the culture of Pietism. In addition, the Lutheran theologians in Copenhagen had grave doubts about the legitimacy of mission work. The Gospel had already been declared all over the world by the Apostles, according to leading theologians such as Niels Hemmingsen (1513-1600) and Hans Resen (1561-1638). They had explained that the Gospel had been declared twice before Christ's arrival. First, it had been preached in the Garden of Eden, to Eve after the fall of man, as a promise that the snake should crush the head of the snake. Second, the Gospel had been declared as a promise to Noah, as part of the pact. Third, after the arrival of Christ, the apostles had preached the Gospel in Jerusalem and everywhere in

\footnotetext{
7 One "Versuchungs-Wüste", as Francke said in one of his sermons. Cf. Johann Anselm Steiger, "Versuchung III. Kirchengeschichtlich", TRE 35,60.

8 Kenneth Scott Latourette, A History of the Expansion of Christianity, vol. 3 (Grand Rapids: Zondervan, 1970), 278.

9 Cf. the translation of the text found in the Danish chancellery by Frederick IV of Denmark, "Royal Appointment and Instructions to the First Missionaries," in Halle and the Beginning of Protestant Christianity in India, eds. Andreas Gross, Y. Vincent Kumaradoss, and Heike Liebau (Halle: Verlag der Franckeschen Stiftungen zu Halle, 2006), 1337.
} 
the world. Hence, the Gospel had already been universally preached and no further mission was necessary. ${ }^{10}$

The king was probably influenced by his court preacher F. J. Lütkens, who suggested the names of the missionary candidates. ${ }^{11}$ In addition to sending missionaries to Tranquebar, in 1714 the king also founded a Collegium to promote missionary work. The foundation of the Collegium was disseminated in a small publication, which also had some remarks concerning Tranquebar. Why would the Danish king send missionaries to India? The answer was King Frederick's care [omsorg] for Christ's Gospel. Apparently, it had "lead to the results that were visible to the whole world through the reports of the Halle Mission: the preaching of the Gospel for the heathens in India."12

The political ideology in Denmark made mission work plausible to some degree. As a Lutheran king, Frederick IV was responsible for both the worldly and the spiritual well-being of all his subjects. When the royal appointment - cited above - stated that the missionaries should preach to the heathens "in our territories," this was in line with the standard Lutheran interpretation. The new element was the addition to carry out missions "in neighbouring regions," because it broke with the confined area of royal rule, the realm of power. ${ }^{13}$

\section{Danish Presence in Tranquebar}

The idea of mission was not a part of the original plan for extending Danish rule to India. Denmark-Norway had gained a foothold at the Coromandel coast in the $1620 \mathrm{~s}$ in order to partake in the wealth that came from the east, as part of the mercantile

10 Jens Glebe-Møller, “Det Teologiske Fakultet 1597-1732,” in Københavns Universitet 1479-1979, ed. Svend Ellehøj (Copenhagen: Gads Forlag, 1980), 196-97. See also Jens Glebe-Møller, "The Realm of Grace Presupposes the Realm of Power: The Danish Debate about the Theological Legitimacy of Mission," in Halle and the Beginning of Protestant Christianity in India, eds. Andreas Gross, Y. Vincent Kumaradoss, and Heike Liebau (Halle: Verlag der Franckeschen Stiftungen zu Halle, 2006). This was more or less a standard view of the Lutherans on the continent, as well. Cf. Matthias Pohlig, Zwischen Gelehrsamkeit und konfessioneller Identitätsstiftung. Lutherische Kirchen- und Universalgeschichtsschreibung 1546-1617 (Tübingen: Mohr, 2007), 398.

11 As provost of Berlin, Lütkens had been a close colleague of Spener, and in 1692 Lütkens had been in a commission evaluating the controversial work of Francke. Cf. Daniel Cyranka and Andreas Wenzel, “'Das eigentliche Portrait des seligen Aarons' - Der indische Prediger Aaron (1698/99-1745) auf Bildern des 18. Jahrhunderts,” in Pietismus Und Neuzeit 35 (2009), 152.

12 "§. VI. Ey heller er det dennem ubevist / som glæder sig ofver Evangelii Løb / eller i det øfrige ere begierlige efter at viide / hvad der skeer i Verden / hvis sig imidlertid har tilldraged i samme Verk / efterdi det ligger for all Verdens Øyne forfatted udi de Ostindiske i Trycken udgangne og continuerede Merkværdige Berettninger.” Johan Georg von Holsten, Kort efterretning om nærværende Anstalt $i$ Dannemark fil Hedningenes Omvendelse (Copenhagen: Johann Sebastian Martini, 1715), 4.

13 Cf. Glebe-Møller, "The Realm of Grace Presupposes the Realm of Power”. 
politics of King Christian IV, who wanted to take part in the lucrative trade that East India represented. ${ }^{14}$

The king had founded the first Danish East India Company in 1616, and challenged Portuguese claims to trade monopoly with India. The local prince, Raghunatha Nayak of Tanjore, was interested in striking a trade agreement with the Danes, probably wishing to balance the foreign powers. Raghunatha granted them permission to build "a stone house" in Tranquebar and collect rent from the village land. In return, the Danes should pay a yearly tribute to the Nayak. ${ }^{15}$ Although religious freedom was secured in the treaty, there were no regulations concerning possible conversions or mission activities. ${ }^{16}$

In line with the other European powers establishing themselves on the Indian coast, military fortifications were erected and the castle "Dansborg" was built. However, one should probably not regard the small trade station of Tranquebar as a large-scale demonstration of Danish colonial power. When the Nayak Raghunatha died and a more hostile Nayak assumed power, the Danish colony was saved by the Indian merchant Achyatappa Chetti and his connections to the Dutch trade company and Indian political rulers. The whole endeavour was "a common project for many Indian actors and a small group of envoys from the kingdom Denmark-Norway."17

\section{Religion in Tranquebar}

The space that emerged in Tranquebar was both multicultural and multireligious. Hindus and Muslims were a natural part of the community, but Roman-Catholic Christians were also received and given the opportunity to erect their own church within the limits of Tranquebar. In 1700, it was even reported that the trade company

14 In the audience room at Fredriksborg castle one can also behold today how the dream of treasures from the East kindled the imagination in Copenhagen. Four paintings from the 1680s depict the continents at that time. The woman of Asia is draped in expensive clothes, holding flowers and incense in her hands. It gives an impression of the "Danish dreams about the glorious things in the east." Søren Mentz, Niels Brimnes, and Esther Fihl, "Indernes verden 1600-1750," in Danmark og Kolonierne: Indien: Tranquebar, Serampore og Nicobarerne, ed. Niels Brimnes (Copenhagen: Gad, 2017), 18. For the economic disaster which the first years in Tranquebar represented, see Ole Feldbæck, "Den danske asienhandel 1616-1807. Værdi og volumen,” Historisk Tidsskrift 15, no. 5 (1990), 323.

15 Esther Fihl, "Shipwrecked on the Coromandel: The First Indo-Danish Contact, 1620," Review of Development \& Change 14, no. 1-2 (2009), 20.

16 Daniel Jeyaraj has translated the treaty into English. In the third article it states: "We are committed always to defend and favour the subjects of the King of Denmark in the practice of their faith, called the Augsburg Confession, and we shall never tolerate that they be oppressed because of their faith.” Jeyaraj, Bartholomäus Ziegenbalg, 263.

17 Esther Fihl and Svane-Knudsen Asger, “Tranquebar etableres 1620-30," in Danmark og Kolonierne: Indien: Tranquebar, Serampore og Nicobarerne, ed. Niels Brimnes (Copenhagen: Gad, 2017), 74-75. 
paid the salary of the Portugese priest. ${ }^{18}$ However, the sole intention of the Danish East India Company was to do commercial work, and to act accordingly. ${ }^{19}$ When the missionaries from Halle arrived in 1706, the company feared that their religious activities would damage the trade activities. The commander, Johan Hassius, considered Ziegenbalg a millennialist, "a Thomas Müntzer, that eventually would ignite a revolution," 20 and he even put the missionaries in jail a few times, due to what he considered revolutionary behaviour. ${ }^{21}$

Indeed, Hassius's remark about the missionaries' heterodox doctrine was not without foundation. One problematic aspect was the political implication of their activity, as the Tranquebar mission was not restricted to care for the spiritual life of the Indians. The missionaries understood their mission as more than merely saving souls - in line with the Pietist ideology from Halle they were concerned with the entire life of the converts. ${ }^{22}$ They reflected the millennial component that was part and parcel of the Pietist package. It was not only Hassius who was sceptical about the new culture brought by Ziegenbalg and Plütschau - Bishop Bornemann who ordained the Halle theologians had also been sceptical and had only accepted them after the king had intervened on their behalf. Negative assessments were published in polemic pamphlets years after their journey to Tranquebar.

One of the most significant pamphlets was published in 1715 under the pseudonym Christianus Aletophilus, portraying the story of the mission critically. ${ }^{23}$ The author remarked sarcastically that the missionaries' presentation of the first New Jerusalem church as a miracle [Wunderwerck] attracted very little money. According to Aletophilus,

18 Niels Brimnes and Helle Jørgensen, "Lokalsamfundet Trankebar," in Danmark og kolonierne: Indien: Tranquebar, Serampore og Nicobarerne, ed. Niels Brimnes (Copenhagen: Gad, 2017), 132.

19 Interestingly, most of the capital of the company came from Jewish and Reformed investors. Therefore, the spread of the Lutheran church was hardly considered as one of its main targets, to say the least. Brimnes and Jørgensen, "Lokalsamfundet Trankebar," 138.

20 Wilhelm Germann, Ziebenbalg und Plütschau: Die Gründungsjahre der Trankebarschen Mission (Erlangen: Deichert, 1868), 114.

21 The conflict between the secular government and the missionaries are often interpreted as a conflict between strong personalities. It was rather a structural conflict, where the missionaries understood themselves having an authority that rested on a royal decree. For the secular government, however, they ultimately represented a threat to trade. Cf. Arno Lehmann and Bartholomäus Ziegenbalg, Alte Briefe aus Indien: Unveröffentlichte Briefe von Bartholomäus Ziegenbalg 1706-1719, ed. Arno Lehmann (Berlin: Evangelische Verlagsanstalt, 1957), 396. Cf. also J. F. Fenger, Den Trankebarske missions historie (Copenhagen: Reitzel, 1843), 43-47.

22 Anders Nørgaard, “The Mission’s Relationship to the Danes," in Halle and the Beginning of Protestant Christianity in India, eds. Andreas Gross, Y. Vincent Kumaradoss, and Heike Liebau (Halle: Verlag der Franckeschen Stiftungen zu Halle, 2006), 173.

23 Printed in Fenger, Den Trankebarske missions historie, 329-58. Fenger claimed that the professor of theology, Hans Bartholin, was the real author of the critical account. 
however, labour was very cheap, and the commander Hassius had supplied a substantial number of the bricks. ${ }^{24}$ Therefore, a main target of the critique was of a theological nature - that the signs of a celestial intervention and Francke's idea that "God himself was building" were hardly tenable, but had worldly causes instead. ${ }^{25}$

One of the most interesting theological problems was a product of the absolutist government itself: how could a minister in the church be rightly called to his work? The Lutheran concept of vocation presupposed a congregation that called a person to the public ministry of the Word, and it was arranged as a defense against selfproclaimed prophets who had seen the light. This concept was not only a result of the religious controversies of the 1520s in Germany, but was also used as a guard against Roman Catholic ecclesiology. In spite of the principle that "the congregation nominates its clergy," power increasingly resided with the king in Copenhagen during the seventeenth century. ${ }^{26}$ In theory this situation was explained by the king acting as a "father" of the congregations, sending out clergy in their name.

The sending of missionaries created a new situation. Orthodox Lutherans saw the danger of Copenhagen becoming a new Rome, where the king would send out pastors without the consent of the congregations. ${ }^{27}$ When the absolute king sent out two missionaries who rested their authority on an inward calling, however, Roman Catholicism and spiritualism seemed to converge with the king's Caesaropapal command structures and the missionaries' dubious personal experiences. The king solved this problem by referring to his cura religionis, the king's fatherly care for his own subjects. In the formal instruction of missionaries, no reference was given to the so-called Great Commission of Matt 28:18-20 "[. . .] Go ye therefore, and teach all nations [. . .].” Instead, the missionaries were sent as clergy to the king's fines tranquebargienses. As Anders Nørgaard has noted, the word fines can also be translated as "neighbouring regions," in addition to "boundaries."28

24 "Was machen sie nicht vor Wesens von dem Bau der neuen Kirche, Jerusalem genannt, von welcher noch Viele in dem Gedanken stehen, es sei derselbigen Erbauung ein Wunderwerk und eine extraordinaire Begebenheit; denn sie wissen nicht, dass dieselbige, weil sie sehr klein ist, nicht mehr als 160 Rth. zur Erbauung gekostet habe; denn die Materialien und die Arbeitsleute kann man in Ost-Indien sehr wohlfeil haben [. . .].” Fenger, Den Trankebarske missions historie 345. 25 Commenting on the success of the Halle institutions, Francke claimed "dass Gott selbst mit im Werck sey.” Cf. Breul, “August Hermann Franckes Konzept einer Generalreform,” 78-79.

26 After the introduction of absolutism in Denmark-Norway in 1660, changes were made in the way ministers were called through a series of royal rescripts. In short, ministers went from being chosen by the congregations and local authorities, to a full integration in the royal government. Cf. Oluf Kolsrud and Kristen Valkner, Presteutdaningi i Noreg, Scandinavian University Books 21 (Oslo: Universitetsforlaget, 1962), 162.

27 Anders Nørgaard, "The Mission Instruction," in Halle and the Beginning of Protestant Christianity in India, eds. Andreas Gross, Y. Vincent Kumaradoss, and Heike Liebau (Halle: Verlag der Franckeschen Stiftungen zu Halle, 2006), 1277-78.

28 Nørgaard, “The Mission Instruction,” 1279. 
Therefore, the missionaries were sent to the Danish colony, but their missionary activity was not confined to that area.

\section{Hope for Better Times}

In addition to being outside the normal lines of authority, the Pietist missionaries had a new understanding of history. They turned away from the apocalyptic view of history of imminent return, where the parousia (second coming) of Christ could break into history anytime, as the orthodox Lutherans had taught. ${ }^{29}$ Instead, Christ would postpone his second coming in order to make sanctification possible, and make conversion to Christianity attractive for Jews and heathens. ${ }^{30}$ The main figure of Pietism, Philipp Jacob Spener, had underlined the "hope for better times."31

Therefore, in the time between the present and the return of Christ, there was not merely Luther's expectation of an imminent return, but the Pietists hoped for a radical betterment, a time when Christians could prepare themselves for the kingdom of God. These utopian aspirations ran contrary to traditional Lutheranism. Already in the Augsburg Confession of 1530, Melanchthon had condemned those who promoted so-called "Jewish opinions" that "the godly will take possession of the kingdom of the world" before the resurrection. ${ }^{32}$

The traditional view could be designated as Augustinian. ${ }^{33}$ Surely, there had been theologians that had challenged such a view of history, ${ }^{34}$ but the Lutheran

29 The literature is immense. See for example Robin Bruce Barnes, Prophecy and Gnosis: Apocalypticism in the Wake of the Lutheran Reformation (Stanford: Stanford University Press, 1988); and Volker Leppin, Antichrist und Jüngster Tag. Das Profil apokalyptischer Flugschriftenpublizistik im deutschen Luthertum 1548-1618 (Gütersloh: Gütersloher Verlagshaus, 1999).

30 Schäufele underlines that both premillennialism and postmillennialism contributed to postponing the end of the world to a more distant future. Wolf-Friedrich Schäufele, "Geschichtsbewusstsein und Geschichtsschreibung um 1700," in Geschichtsbewusstsein und Zukunftserwartung in Pietismus und Erweckungsbewegung, eds. Wolfgang Breul and Jan Carsten Schnurr (Göttingen: Vandenhoeck \& Ruprecht, 2013), 43.

31 As Krauter-Dierolf has shown, on the one hand Spener was anxious to distance himself from millennarian interpretations, while on the other hand he did not reject that the "glorious Kingdom of Christ” was at hand. Heike Krauter-Dierolf, Die Eschatologie Philipp Jakob Speners: Der Streit mit der lutherischen Orthodoxie um die "Hoffnung Besserer Zeiten", Beiträge zur historischen Theologie (Tübingen: Mohr Siebeck, 2005), 51-53.

32 Irene Dingel and Bastian Basse, Die Bekenntnisschriften der evangelisch-lutherischen Kirche, Vollständige Neued. ed. (Göttingen: Vandenhoeck \& Ruprecht, 2014), 112-13.

33 Augustine, after he had rejected millenial views around AD 400. Cf. Robert A. Markus, "History," in Augustine through the Centuries, ed. Allan O. S. A. Fitzgerald (Grand Rapids: Eerdmans, 1999), 433. 34 Cf. Johannes Wallmann, "Zwischen Reformation und Pietismus. Reich Gottes und Chiliasmus in der lutherischen Orthodoxie," in Verifikationen. Festschrift für Gerhard Ebeling, eds. Johannes Wallmann, Wilfried Werbeck, and Eberhard Jüngel (Tübingen: Mohr, 1982); and Walter Sparn, “'Zeit- 
theologians as a group were sceptical of any idea that could justify a realization of New Jerusalem before the world came to an end. One problem was simply that there was no time left, as Luther's apocalyptic world-view had created an expectation of an imminent return of Christ. The world was expected to last some six thousand years, and would perhaps come to an end tomorrow. ${ }^{35}$ Another reason was that the traditional anthropological imagery of a "battle" within Christian persons until the end - between spirit and flesh precluded any optimistic idea of qualitative progress. $^{36}$

The chiliastic ideas that Spener and Francke promulgated ${ }^{37}$ can be seen on many levels of their work. Both the more lofty ideas of the Halle Institute as the germ cell of a "general reformation of the world" 38 and the more concrete export of the school system had utopian aspects. Indeed, in Denmark, too, Francke's institutions in Halle were understood as "a pedagogical Jerusalem."39

The aspirations to create a better world did not lead to dreaming and speculations for the missionaries. Entering a new culture, they had to learn both Portuguese and Tamil. Following biblical practice, they drew lots about who should study the languages and Ziegenbalg was chosen to become a student of Tamil. From his study of the language from the Tamil Brahmins and high-caste teachers, Ziegenbalg acquired an in-depth knowledge of the local culture and religious beliefs. As a result, he published many works, among which his book on Genealogy of the South-Indian Gods is the best known.

The acquired knowledge was used specifically for missionary purposes. When the commander Hassius made an effort to recruit the missionaries for school work, they turned the question around and asked if Hassius would not help them in their mission efforts. ${ }^{40}$ Their understanding of their divine calling - and therefore zeal for saving Indian souls from eternal damnation on the path to true morality was

Ordnung'. Der antichiliastische Haupt-Schlüssel über die hohe Offenbarung S. Johannis von Caspar Heunisch (1684)," in Frömmigkeit, Bildung, Kultur. Theologische Aufsätze 1: Lutherische Orthodoxie und christliche Aufklärung in der frühen Neuzeit (Leipzig: Evangelische Verlagsanstalt, 2012).

35 Gustav Adolph Benrath, “Geschichte/Geschichtsschreibung/Geschichtsphilosophie VII/1. 16. bis 18. Jahrhundert,” in TRE 12,630.

36 Bengt Hägglund, De Homine: Människouppfattningen i äldre luthersk tradition, vol. 18 (Lund: Gleerup, 1959), 399.

37 Claus Bernet, "Expectations of Philadelphia and the Heavenly Jerusalem in German Pietism," in A Companion to German Pietism, 1660-1800, ed. Douglas H. Shantz, Brill's Companions to the Christian Tradition 55 (Leiden: Brill, 2015), 141.

38 “[...] zur Beförderung des gantzen Wercks des HErrn, und zu einer rechten universalVerbesserung.” A. H. Francke, Der grosse Aufsatz (Berlin: Akademie-Verlag, 1962), 49. See also Chapter 2 (Walter Sparn), vol. 3, 55-73.

39 Charlotte Appel and Morten Fink-Jensen, Da læreren holdt skole: tiden før 1780, Dansk skolehistorie 1 (Aarhus: Aarhus Universitetsforlag, 2013), 166.

40 Nørgaard, “The Mission’s Relationship to the Danes,” 168-69. 
unequivocal..$^{41}$ The metaphor of light and darkness played an important role. When the king wanted to hear Ziegenbalg preach, the latter chose the words of the Acts of the Apostles 26:17-18. Here, St Paul was sent to heathens " $[t] 0$ open their eyes, and to turn them from darkness to light, and from the power of Satan unto God [. . .].” Ziegenbalg was convinced that they contained a message for him and his missionary service. $^{42}$

The missionaries saw the place they entered as a pagan place and could show little appreciation for local religious customs. Their monotheistic faith created a feeling of cultural superiority which also implied intolerance. On one trip, Ziegenbalg destroyed the stone god-heads of a local temple in a kind of prophetic fervour, and he refused to remove his shoes when he visited a local Sufi master. ${ }^{43}$ In a letter to a friend in Germany, written shortly after his arrival in Tranquebar, Ziegenbalg claimed that the magnitude of the heathens' blindness "cannot be mentioned." On a trip in the area, Ziegenbalg saw a pagoda with thousands of idols and was astonished "why the otherwise clever Malabaric people could cling to their futile idols." Nevertheless, he retained the hope that this practice stood only on sand, and would easily fall "when God will have his time."44

Conversely, the Pietist mentality was also well designed for self-criticism in respect to their own culture. The name of Christ was a source of shame for the indigenous people, Ziegenbalg wrote, due to the alleged low moral standard of the Westerners. ${ }^{45}$ Already in October 1706, in a letter to Franck, Ziegenbalg had changed his attitude and claimed that the Malabaric people were very wise and rational people - they wanted to be converted by wisdom. According to him, they were "far more directed towards the future life, than were the atheist Christians." ${ }^{46}$ Their ability to criticize

41 Israel Selvanayagam, "Encountering the Hindus: The Legacy of Ziegenbalg," In Halle and the Beginning of Protestant Christianity in India, edited by Andreas Gross, Y. Vincent Kumaradoss, and Heike Liebau (Halle: Verlag der Franckeschen Stiftungen zu Halle, 2006), 903.

42 Jeyaraj, Bartholomäus Ziegenbalg, 37.

43 D. Dennis Hudson, Protestant Origins in India: Tamil Evangelical Christians, 1706-1835, Studies in the History of Christian Missions (Grand Rapids: Eerdmans, 2000), 17-20.

44 "Die grosse Blindheit der Heiden ist nicht auszusprechen. [. . .] Ich war den 18. August mit des Commandanden Pferd ein wenig ins Land hinein und kam zu einer Pagode, um welche viel tausend Götzen herumstunden und vor deren Thür zwei mächtige grosse Teufel waren, also dass ich mich billig verwunderte, dass die sonst klugen Malabaren so hartnäckig an solchen ihren nichtigen Götzen desto leichter fallen werde, wenn Gott hierzu seine Zeit ersehen haben wird.” Lehmann and Ziegenbalg, Alte Briefe aus Indien, 35.

45 For example from a letter dated 25 September 1706 Ziegenbalg wrote that "the name of Christ is so hated and despised among them [the Malabaric people] due to the annoyingly and disgraceful behaviour of the Christian. Hence, they [the Malabaric people] believe that there are no more evil people [the Christians] in the world.” Ziegenbalg, Alte Briefe aus Indien, 40.

46 "Es sind aber diese malabarischen Heiden ein sehr kluges und verständiges Volk, welche da mit grosser Weisheit wollen gewonnen werden. [. . .] Sie sind von dem zukünftigen Leben weit kräftiger überzeugt als die atheistischen Christen.” Ziegenbalg, Alte Briefe aus Indien, 44. 
both Indian religious customs and European ethical standards strengthened the mission's own raison d'etre as an instance of reform and renewal.

\section{School and Church}

The missionaries started the work to erect their own mission church soon after their arrival in Tranquebar. The Danish and German population held their services at Zion Church, but the missionaries were not allowed to use it. Already in August 1707, however, they were able to move into the humble New Jerusalem church inside the confines of the city. The commander had allotted a place for them in the Indian quarter, and they had succeeded in building a church. In Ziegenbalg's diary, he remarked that for the consecration of the first New Jerusalem church, they gathered thousands of people from all the nations, and the report gave an overwhelmingly positive account:

Today, our church was consecrated in the name of the Trinity and given the name Jerusalem. 6 o'clock in the morning, colleagues were preaching in Portuguese and in the afternoon, I gave a sermon in Malabaric. Many thousands of Malabars, Moors, Portuguese, Germans, and Danes were present. God gave me a particular gift, namely to speak joyously in their own language. The consecration stirred up the whole town. ${ }^{47}$

As the text of his sermon, Ziegenbalg chose the text from Ps 122:6: "Pray for the peace of Jerusalem: they shall prosper that love thee." The centrality of this Jerusalem-text for the missionaries is seen by the fact that the copper plate handed over by the church foundation a decade later, had the same verse engraved in Danish. ${ }^{48}$

Along with missionaries, the first five converts - those who had been baptized in May the same year - followed them into the new church. One year later, there were over 100 converts in the congregation. In a letter to Francke dated October 1707, he told him that "already 3 have been baptized in our new Jerusalem." Many signs of progress are reported by Ziegenbalg and the effect of New Jerusalem in Tranquebar can easily be interpreted as the dawn of a new age. One man had been freed from temptation [Anfechtung] of the Devil; the new faith had helped him to overcome it. In addition, his sick child became healthy after the baptism, and as a result the

47 "Heute wurde im Names des dreieinigen Gottes unsere Kirche eingeweiht und ihr der Name Jerusalem gegeben, da denn des Morgens früh um sechs Uhr bei einer großen Frequenz von meinem Collegen eine portugiesische Rede und Nachmittags von mir eine malabarische Rede gehalten wurde: da denn etliche tausend Malabaren, Mohren und Portugiesen, Deutsche und Dänen zugegen waren. Gott erzeigte mir sonderliche Gnade, dass ich mit einer großen Freudigkeit in der gleichen Sprache reden konnte. Diese Einweihung machte die ganze Stadt rege.” Germann, Ziebenbalg und Plütschau, 71. 48 Jeyaraj, Bartholomäus Ziegenbalg, 152-53. 
whole town was full of joy. ${ }^{49}$ By describing these signs, Ziegenbalg balanced very carefully between the possibility of perceiving his missionary effort as the realization of the glorious kingdom of God and viewing it merely as a sign of a particularly blessed work.

For a modern reader the reported numbers may seem quite overwhelming, prompting the question of why the Indian people of Tranquebar would convert to Pietist Christianity. The sources suggest a number of reasons, some of a more economic and strategic nature. However, in the public debate with local learned men, the different doctrinal aspects of the religions were compared and discussed, and some converts cited their spiritual searching as a major cause for their baptism. ${ }^{50}$ For the missionaries, this was the most important cause. Ziegenbalg compared their situation to that of the people of Israel when they were enslaved in Egypt and wrote: "God had finally heard their groaning." 51

Indeed, the structure of their narrative resembled Israel's exodus from Egypt. Before Ziegenbalg and Plütschau could lead the converts into the New Jerusalem church, they had encountered many obstacles in pursuing "the holy work." Ziegenbalg wrote that their work had happened under the "cross and temptations," with "fierce resistance and hard trials." ${ }^{2}$ He mentioned their tireless work with language and catechism instruction in detail, even the number of hours per day. However, the fruit of their labour was evident and was clearly a sign of progress as Ziegenbalg saw it: "The more the number of Christians increased, the more the missionaries' efforts increased and in addition, the more God's grace and power in our soul and bodies increased." 53

The last obstacle for the missionaries was to build a church, according to Ziegenbalg. He saw the difficulties of raising the house of God in a dramatic light, and it was possible to interpret it as the dark forces of Babel resisting the progress of the New Jerusalem: "When the Devil noticed it [the plan to build a church], he used

49 "[. . . ] 3 in unserm neuen Jerusalem getauft worden und auch ein paar getraut und kopuliert, dadurch die ganze Stadt in Freude gesetzt wurde, zumal weil die eine Mannsperson, ehe als sie getauft wurde, überaus grosse Anfechtung vom Teufel hatte, aber ihn gleichwohl durch den Glauben überwand. Dessen Kind gleichfalls nach der Taufe frisch und gesund wurde, da es doch vorher auf (den) Tod krank darniederlag." Lehmann and Ziegenbalg, Alte Briefe Aus Indien, 69.

50 Brimnes and Jørgensen, "Lokalsamfundet Trankebar," 143.

51 "[. . .] das doch unsere Christliche Religion auch unter den Heyden möchte fortgepflantzet werden / so hat GOtt endlich ihr Seufzen erhöret [. . .].” Bartholomäus Ziegenbalg, Ausführlicher Bericht [..] ertheilet / den 22ten Augusti 1708 (Halle: Wäysen-Hause, 1710), 6.

52 "Vor allen Dingen muss ich bekennen / dass gleichwie dieses heilige Werck unter grossem Widerstand und unter sehr vielem Creutz und Anfechtung seinen Anfang genommen / es auch bishiehero nicht anders als unter heftigem Widerstand und allerley harten Prüfungen können fortgeführet werden [. . .].” Ziegenbalg, Ausführlicher Bericht, 6.

53 "Jemehr sich nun die Zahl der Christen vermehrete / ie mehr vermehrete sich auch unsere Arbeit / und je mehr sich unsere Arbeit vermehrete / je mehr vermehrete sich auch die Gnade und Kraft GOttes an unser Seele und Leibe [. . . ].” Bartholomäus Ziegenbalg and Johann Gründler, Achtzehende Continuation des Berichts derer königl. dänischen Missionarien (Halle: Wäysen-Hause, 1724), 7. 
all his force to prevent such an intention.” The missionaries, however, were not deterred, and raised the church in the midst of the Malabars for 250 perdous. It was consecrated on 14 August 1707 and named New Jerusalem. "God has blessed this Jerusalem so far, and filled it with new Christians from the heathens to the point that there is almost no room left. This is a sign, indicating that God soon will give aid to an expansion." 54

In another report, however, Ziegenbalg reflected on the sceptical attitude towards external worship that characterized Pietism. A true Christian service for Ziegenbalg and his readers of the news from East India was first and foremost located internally, in the heart, impossible to see with the external eye. The concrete church building was therefore a challenge and in need of an interpretation. Still, as a practical missionary, Ziegenbalg saw the importance of public worship:

[. . .] in spite of all obstacles God has not forsaken us in our confidence in him. Indeed, we know - by the grace of God - that an evangelical worship of the New Testament is an internal and invisible affair. The external Temple cult, that so much of Christianity has fallen into again, is not certain. Still, God is a God of order. He does not want his children to pray and worship him internally at home, he wants to be worshipped and honoured both externally and publicly. ${ }^{55}$

When Ziegenbalg commented on the mission strategy, the work among the youth was of paramount importance. "If one aims to do something among the heathens that will have a lasting effect, then most of the plans must be directed at the youth." $" 56$ One of the efforts the missionaries made was to provide free education. This was arguably the core of Francke's Halle-project from the start: a theologically grounded and pedagogically actionable concept of upbringing, "to instruct the children to true divine bliss [Gottseligkeit] and Christian wisdom.” As a result, religious education became the dominant tenor of the movement. ${ }^{57}$ In one of Francke's

54 Ziegenbalg and Gründler, Achtzehende Continuation des Berichts derer königl. dänischen Missionarien, 7-8.

55 “[. . .] gleichwol hat uns GOtt in unsern Vertrauen nicht stecken lassen. Zwar wissen wir durch GOttes Gnade wol / dass der Evangelische GOttes-Dienst des neuen Bundes fürnemlich aufs innere und unsichtbare zu führen sey / und es mit dem äusserlichen Tempel-Wesen / auf welches man es in der Christenheit hin und wieder leyder hauptsächtlich ankommen läst / gar nicht ausgemachet sey; Jedoch aber weil Gott ist ein GOtt der Ordnung; und von seinen Kindern nicht allein innerlich und daheim / sondern auch äusserlich und offentlich wil angebethet und verhret seyn [. . .].” Bartholomäus Ziegenbalg, Fortsetzung der Merckwürdigen nachricht aus Ost-Indien (Berlin: Pape, 1708), 6.

56 Cited from Heike Liebau, "Faith and Knowledge: The Educational System of the Danish-Halle and English-Halle Mission," in Halle and the Beginning of Protestant Christianity in India, eds. Andreas Gross, Y. Vincent Kumaradoss, and Heike Liebau (Halle: Verlag der Franckeschen Stiftungen zu Halle, 2006), 1182.

57 “[. . . ] die Kinder zur wahren Gottseligkeit und Christlichen Klugheit anzuführen.” Cited from Udo Sträter, "Das Waisenhaus zu Glaucha vor Halle," in Kinder, Krätze, Karitas. Waisenhäuser in der frühen Neuzeit, eds. Claus Veltmann and Jochen Birkenmeier (Halle: Franckeschen Stiftungen, 2009), 78. 
earliest treatises, Von der Erziehung der Jugend zur Gottseligkeit, he underlined that the cultura animi, the care of souls, had two components - will and reason. It was paramount for Francke that the "natural self-will [Eigenwille] should be broken" in order to bring the will under obedience. A common mistake was, according to Francke, to merely care for reason. ${ }^{58}$ Obedience was necessary for making the soul elastic enough for the formation of the new society.

The missionaries in Tranquebar were influenced by the same ideas. They were very interested in the discussion of how education could be developed, and took part in a correspondence about pedagogical concepts with English missionaries. ${ }^{59}$ In a letter to the English chaplain in Madras, the missionaries in Tranquebar described their educational practice in detail. ${ }^{60}$ It was first written in Portuguese, but later translated into English and printed in London. ${ }^{61}$ It was obvious, they wrote, that "the general Good of any Country or Nation depends upon a Christian and careful Education of Children in Schools."62 The Tranquebar missionaries saw it as their calling, "that Men may be turned away from their abominable Idolatry unto the Living God [. . .],"63 and the school was an important instrument for that purpose. When they explained the order of a typical day at school for the older boys, its extremely tight schedule mirrored their construction of the ideal society:

6-7 am: catechism and prayer with a missionary

7-9 am: a chapter is read from New Testament, with breakfast in between.

9-11 am: classes with repetition. The oldest pupils are introduced to Malabarian poetry, in order to demask their "abominable doctrines", namely their alleged idolatrousness.

11-12 am: lunch

$12-1 \mathrm{pm}:$ rest

1-2 pm: reading Portuguese

2-4 pm: writing

4-6 pm: arithmetic

6-730 pm: catechetical meeting, where they discuss the morning instruction of the missionary. ${ }^{64}$

58 A. H. Francke, "Kurzer und einfältiger Unterricht, wie die Kinder zur wahren Gottseligkeit und christlichen Klugheit anzuführen sind,” in A.H. Francke's Pädagogische Schriften, ed. Gustav Kramer (Langensalza: Hermann Beyer, 1885), 19.

59 Heike Liebau, Cultural Encounters in India (London: Routledge, 2018), 379.

60 Interestingly, the letter was originally printed in Portuguese on the mission's printing press in Tranquebar.

61 Jeyaraj, Bartholomäus Ziegenbalg, 172.

62 Bartholomäus Ziegenbalg and Johann Gründler, A Letter to the Reverend Mr. Geo. Lewis (London: J. Downing, 1715), 1.

63 Ziegenbalg and Gründler, A Letter to the Reverend Mr. Geo. Lewis, 2.

64 Ziegenbalg and Gründler, A Letter to the Reverend Mr. Geo. Lewis, 4-6. The 1709 school regulations are printed in Liebau, Cultural Encounters in India, 380. An early report of the school regulation can be found in a letter from Ziegenbalg to the Court Preacher Lütkens in Copenhagen, dated 22 August 1708. Cf. Lehmann and Ziegenbalg, Alte Briefe aus Indien, 73-74. 
An interesting glimpse in the learning of gestures was given by Ziegenbalg in a letter to F. J. Lütkens in Copenhagen, dated 22 August 1708. He had taken eight children into custody in his own house, given them food and clothing, and employed two teachers [praeceptors] to train them. When he described the order of the day, Ziegenbalg mentioned that the children should start the day by prayer, falling on their knees together with the teachers. He added that all parents who wanted to join the congregation would have their school expenses and living costs paid for, in order to "educate them by our own hands, and among them find people who can contribute to the expansion of the Christian religion." 65

The connection between concrete pedagogical measures and the strategic goal of a future expansion of Christianity was clearly a reflection of Francke's idea of a cell that could grow in society. It differed in one important sense, however, as Halle was a project within an old Christian culture, whereas in Tranquebar, it was more than a reformation, but rather was the growth of Christianity itself.

\section{The New Jerusalem Church}

The first New Jerusalem church was too small and impractical for the congregation of the Halle missionaries. The church which they later built was also called "New Jerusalem," inaugurated in 1718. It was designed by architect Leonard Christoph Sturm (1669-1719), one of the proponents of Architectura Sacra, and a drawing of the church can be identified as from as early as 1711 (Fig. 21.2a-b). ${ }^{66}$ Instead of treating aesthetical religious theory of art as the subject matter of architecture, the theoreticians who promoted Architectura Sacra merely proposed biblical subjects, such as the Ark of Noah, the Temple of Solomon, the Temple of Ezekiel, and the New Jerusalem. ${ }^{67}$

Sturm was heavily influenced by the work of the Dutch Nicolaus Goldmann (1611-65), a jurist, mathematician, and architectural theorist, who wrote the treatise Architectura sacra some time before 1660, although it remained unpublished. Goldmann's Anweisungen zu der Civil-Bau-Kunst was published posthumously by Sturm

\footnotetext{
65 "Ich habe mit meinem Collegen zu der Jugend eine dermassen grosse Liebe, so, daß wir beyderseits beschlossen, alle Kinder, so da mit ihren Eltern zu unserer Gemeinde treten möchten, frey zu unterhalten, um daß wir sie desto besser nach unser eigenen Hand erziehen können, und unter ihnen stets solche Leute finden mögen, so da künftig zur Ausbreitung der Christlichen Religion können gebrauchet werden.” Lehmann and Ziegenbalg, Alte Briefe aus Indien, 79.

66 Bernet, "Sturm, Leonhard Christoph", BBKL XIX (2001), 1349-1369.

67 Claus Bernet, "Gebaute Apokalypse": Die Utopie des himmlischen Jerusalem in der frühen Neuzeit (Mainz: Phillip von Zabern, 2007), 219.
} 
in 1696, and Sturm included large parts of the Architectura sacra in his publication. At the core of Goldmann's theory was the idea that architecture was given by God, and that its main expression was the Temple of Solomon. Goldmann believed that the vision of Ezekiel had finally been realized in Solomon's building. ${ }^{68}$ Even the architectural insights of the heathen Roman Vitruvius were taken from that temple, Goldmann claimed.

In his description of the inventors of architecture, Goldmann claimed that

the invention of the art of architecture was given by the hand of the Lord directly [rühret ohne Mittel her]. That is how David gave witness to his son Solomon, after he had given him the pattern or model of the arch, the Temple, the main room and the chambers, namely that he had received everything from the hand of the Lord, in order that he should understand all the model's works. ${ }^{69}$

The direct transmission from God of such divine architecture secured for the realized buildings their rank as being the most perfect. In Sturm's publication, Goldmann referred to the disappointment that the old men felt by the sight of the second Temple, how they wept, because they had seen the old Temple, the one that had been constructed according to the heavenly plan. ${ }^{70}$

When the Greeks built Constantinople for the Emperor, they had spoiled their opportunity to recover the art of construction [Bau-Kunst], however. They draped the buildings with too many ornaments, Goldmann wrote, and as a result, they appeared feminine and prostitute-like. ${ }^{71}$ The ornamentation was one of the main vices of the time $^{72}$ which, according to Goldmann, was allegedly transported back to Rome, as

68 Jeroen Goudeau, "The Matrix Regained: Reflections on the Use of the Grid in the Architectural Theories of Nicolaus Goldmann and Jean-Nicolas-Louis Durand," in Architectural Histories (2015), 3.

69 "Die Erfindung der Bau-Kunst / rühret ohne Mittel her / von der Hand des Herren; dann also bezeuget David seinem Sohn Salomon / nach dem er ihme das Muster oder Vorbild der Lauben / des Tempels / des Obersaales / und der Kammern gegeben hat / dass er alles embfangen habe / von der Hand des Herrn / damit dass er verstünde alle Wercke des Vorbildes.” Leonard Cristoph Sturm, Nicolai Goldmanns vollständige Anweisung zu der Civil-Bau-Kunst (Braunschweig: Heinrich Ketzlern, 1699), 2-3. 70 Sturm, Nicolai Goldmanns vollständige Anweisung 3.

71 The whore was a favourite image - particularly in its New Testament Apocalypse feature - for the fallen church among the Pietists, particularly in the radical wing. See for example the extreme use by Friedrich Breckling, Mysterium Babylonis \& Sionis (Amsterdam: 1663), 19; See also Chapter 17 (Otfried Czaika), 303-05.

72 "Nachdeme der Römer Gebäue kümmerlich auffgeführet waren / seyn durch des Keysers Constantini Entrüstung / die vortrefflichtsten Kunstwsercke abgebrochen / und in seine neue Stadt Byzanz, welche er Constantinopel / oder neu Rom / genennet hat / versetzet worden. Durch diese Ubung gelangten die Griechen wiederum zur Bau-Kunst: Aber diese Griechen haben sich so undanckbahr gegen diese Kunst erwiesen / dass sie dieselbe / durch allzu viel Schmücken / ganz weibisch und hurisch gemacht haben: Welches Laster der damahligen Zeiten Beschaffenheit zuzuschreiben ist." Sturm, Nicolai Goldmanns vollständige Anweisung, 4. 
seen in, for example, the triumphal arch of Constantine. Consequently, the new aesthetic ideals that Sturm promoted were quite austere, stripped of decorations and embellishments. ${ }^{73}$ For Goldmann, the Temple of Ezekiel was a grid system and the square quad was the organizing principle (Fig. 21.1).

Sturm's plan of the New Jerusalem church in Tranquebar reflected not only Goldmann's ideals, but also his fundamental preoccupation with the square as the systemic core. The church was almost a copy of the principles of Goldmann.

\section{The Sermon [Einweihungs-Predigt]}

Ziegenbalg held the consecration service of the second New Jerusalem church on 11 October 1718, and it was reported in the Halle accounts.

His sermon started with a prayer. Ziegenbalg told the triune God about what was to happen, namely a consecration with prayer, holy hymns, preaching, and the holy sacrament. "You would look upon us and bless our undertaking." ${ }^{74}$ Immediately after the report that God indeed would bless the house, Ziegenbalg assured both God and his congregants that "we know very well, that you do not need to dwell in a building built with human hands."75 Nevertheless, the church should be protected from "worldly and domestic use," and dedicated solely to spiritual use. ${ }^{76}$ "Spiritual" was defined in a traditional Lutheran way, as the preaching of the Gospel and the administration of the sacraments.

A key reference in the sermon was from Isa 66:1 where it is said that "the heaven is my throne, and the earth is my footstool." This verse relativized the particularity of the church as the place where his glory dwelled, and emphasized even more the instrumental quality of the concrete building - it was a house with a peculiar goal [Zweck],

73 The sceptical attitude towards bells and whistles can be discerned on a literal level as well. For example, in the preface of the Civil-Bau-Kunst, when Sturm wished to state that he would express himself straightforwardly, he wrote: "I will tell you, without the pomp and glitter of oratorical prose" [ohne alle Oratorische Schmincke]. Leonard Cristoph Sturm, preface to Nicolai Goldmanns vollständige Anweisung zu der Civil-Bau-Kunst (Braunschweig: Heinrich Ketzlern, 1699), XVII.

74 "Du wollest also von deinem Heiligthum auf uns herab schauen, und unser Vornehmen segnen!” Ziegenbalg and Gründler, Achtzehende Continuation des Berichts, 292.

75 "Wir wissen zwar wohl, daß du zu deiner Wohnung kein Gebäude, die Menschen Hände aufführen, vonnöthen hast [. . . ].” Ziegenbalg and Gründler, Achtzehende Continuation des Berichts, 292.

76 "wir weihen anietzo in dem Namen des dreyeinigen Gottes diese Kirche ein; durch welches Einweihen wir dieses Gebäude von allem weltlichen und häuslichen Gebrauch absondern, und es allein zu dem Gebrauch geistliche Handlungen widmen [. . .].” Ziegenbalg and Gründler, Achtzehende Continuation des Berichts, 294. 

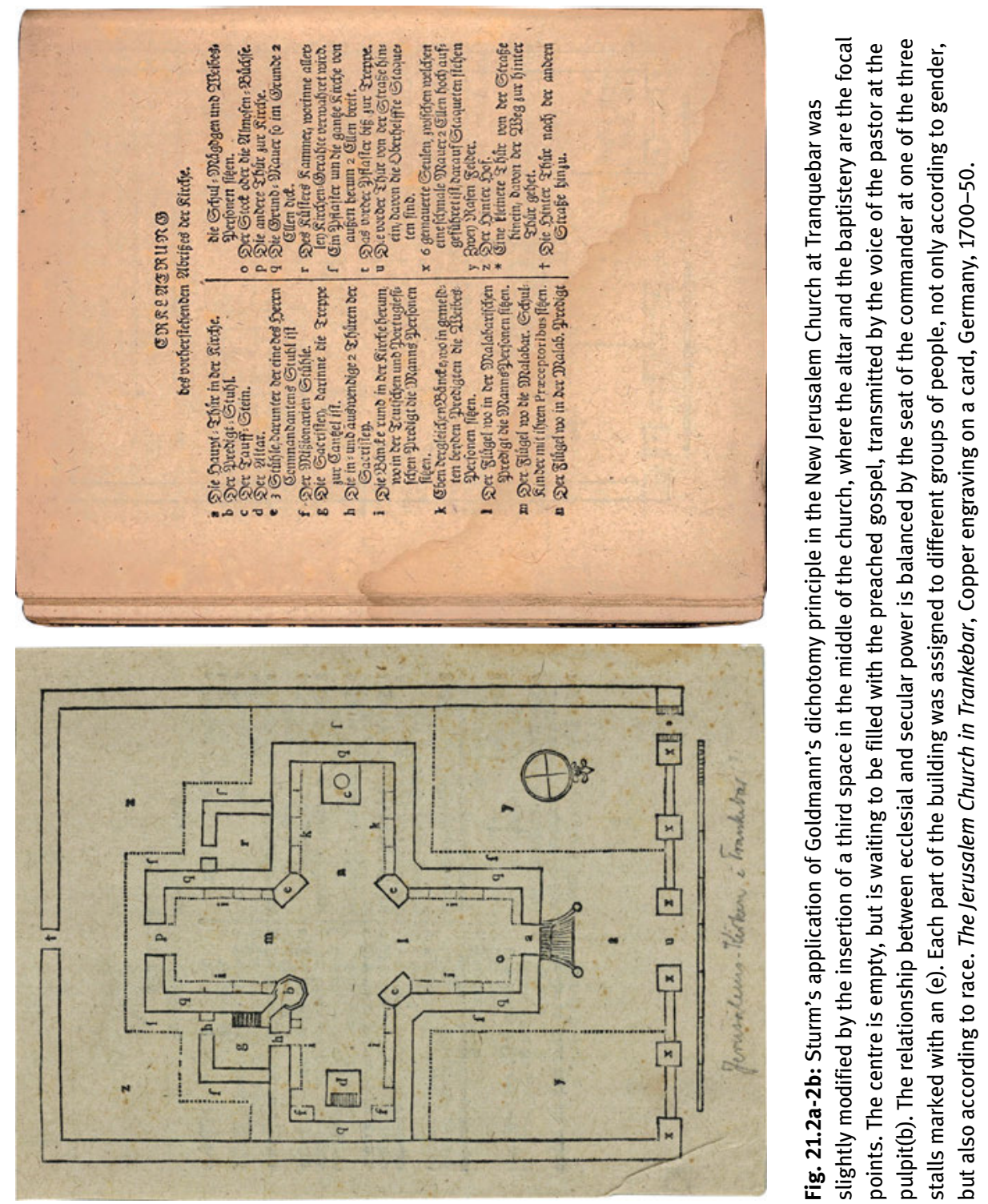
that people may hear the word and "would feel your powerful presence in their hearts, and the divine grace and heavenly blessing could be for salvation of their souls."

The old house was not big enough, but too narrow, due to the fact that "the gospel always needs more space," as Ziegenbalg emphasized. "Oh! Let your glory in this house be greater than the former." 78 This was immediately qualified as something more and different than an external building becoming larger. Of prime importance was his conviction that "more conversion" was needed in the land of the heathen - that is, a true conversion and salvation of the souls of the heathen, because the congregation knew that a conversion of a single soul was more important than the erection of a large external church building.

Ziegenbalg elaborated on the motive of ex oriente lux [light from the east], the reference to Christ as coming with the morning light, conquering the dark forces of the heathen place: "In these latter days, may the dark Orient become bright through the expulsion of the condemned paganism and through the erection of the true Christianity." For Ziegenbalg, therefore, the conversion of the indigenous Tamil people was the main intention, although such a task was not easy. "May we Christians not be an obstacle to the conversion of the heathens." (Fig. 21.3). ${ }^{79}$

He proceeded to explain the name of the church, giving several reasons for the name "New Jerusalem." 80 In the Old Testament, Ziegenbalg explained, Jerusalem was the place where God had revealed "most of the richness of his grace and mercy" to the Jewish Church [!]. In addition, Jerusalem was the place of gathering for all of Israel's tribes. It was the place where God had his stove and his fire. In fact, the Lord himself had said: "I want to dwell in Jerusalem," as Ziegenbalg stated with reference to the book of Zachariah. ${ }^{81}$ In the New Testament, however, the Gospel "sounded" from Jerusalem into the entire world, according to the Gospel of Luke $24 .{ }^{82}$ Ziegenbalg

77 "[.. .] dein Wort zu hören, deine kräftige Gegenwart an ihren Hertzen fühlen, und deiner Göttlichen Gnade und himmlischen Segens zu ihrer Seelen Heyl theilhaftig werden mögen.” Ziegenbalg and Gründler, Achtzehende Continuation des Berichts, 292-93.

78 "Und da solcher Gemeinde das vorige Versammlungshaus zu enge worden, so machtest du deinem Evangelio immer mehrern Raum [. . .] Ach! Laß denn nun die Herrlichkeit dieses letzten Hauses grösser werden, denn des ersten gewesen ist [. . .].” Ziegenbalg and Gründler, Achtzehende Continuation des Berichts, 293.

79 "Laß es zu diesen letzten Zeiten in disem finstern Orient licht werden, durch Vertreibung des verdammlichen Heydenthums, und durch Anrichtung des wahren Christenthums. Laß uns, die wir Christen sind, und in diesen” Ziegenbalg and Gründler, Achtzehende Continuation des Berichts, 293-94. 80 "Und weil es gebräuchlich ist, dass man einer ieden Kirche bey ihrer Einweihung einen Namen gebe, so geben wir auch dieser Kirche einen Namen, nemlich NEU-JERUSALEM: zu welcher Benennung wir unterschiedliche Ursachen haben." Ziegenbalg and Gründler, Achtzehende Continuation des Berichts, 295-96.

81 “Gott selbst saget Zach. 8,3. Ich will zu Jerusalem wohnen.” Ziegenbalg and Gründler, Achtzehende Continuation des Berichts, 295.

82 “[. . .] dass aus selbiger [Jerusalem] die Verkündigung des Evangelium aller Welt verkündiget werden.” Ziegenbalg and Gründler, Achtzehende Continuation des Berichts, 295. 


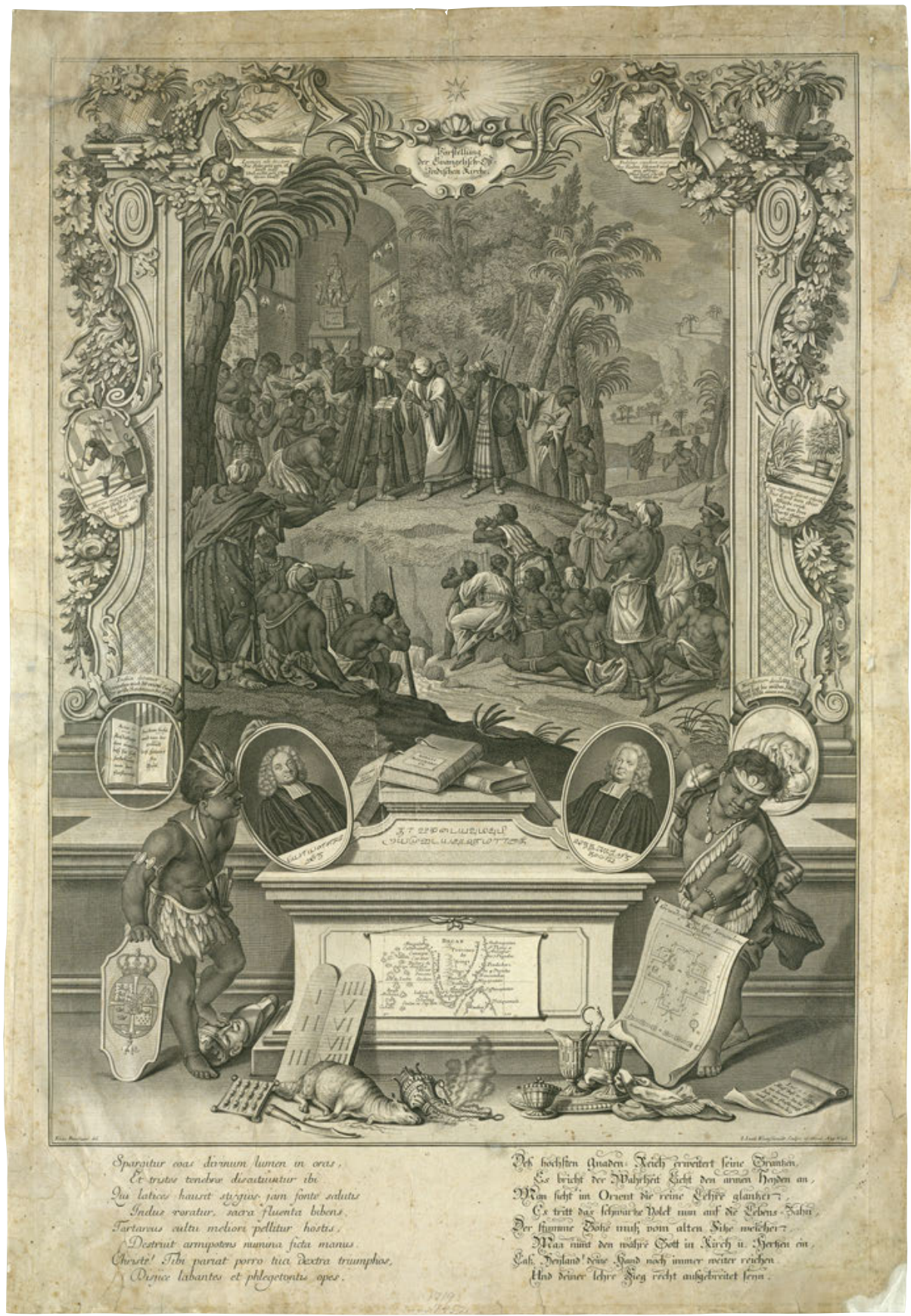

Fig. 21.3: Engraving by I, lacob Kleinschmidt, 1730, representing the arrival and success of the Evangelical church is East-India: the Malabarians turn their back to their former divinity and flock around the around the preaching missionary, The mission aimed to do for the Indians what God hd told St paul to do for the heathens, according to Acts 26:18: "To open their eyes, and from the power of Satan unto God”. The Royal Danish Library (Det Kongelige Biblioteks billedsamling), Copenhagen. 
paralleled the situation of the first apostles to their own work. In the beginning of their missionary activity, there were only five baptized members of the Jerusalem church (the first church). Now, however, through the blessing of the Lord, as Ziegenbalg emphasized, the congregation had so many listeners that a new church was necessary. By interpreting the rapid growth of baptized members as the fruit of good works, Ziegenbalg could state: "We have the childish trust in God, that God, through his blessing, has increased the numbers of heathens." 83

They wanted to keep the name of the church, which had changed from the Zion to the New Jerusalem Church in order to show the harmony and union between Zion and Jerusalem. Further, it was important that everyone could acknowledge that "one walks in one spirit and one mind," because "unity is the most powerful tool to destroy the kingdom of Satan and to erect the kingdom of Christ."84 However, as this church was built for those who by God's word were gathered from the heathen to the congregation of Christ, Ziegenbalg pronounced, he had chosen a text about conversion of the heathen. He proceeded to describe the futility of pagan worship, with the key text from Rom 1:25: they had "worshipped and served the creature more than the Creator." 85

It was important for Ziegenbalg to stress that conversion did not mean solely a conversion from heathen existence, but a conversion to God. An "internal change of the heart" was needed. It was not enough to leave the external horror of the heathen existence; one was called to fight the internal horror of the heart. The converts needed to learn to acknowledge the essence of their sinful existence, and be led to a certain psychological state of mind - Ziegenbalg pleaded for a "divine sadness" [göttlichen Traurigkeit] with a contrite and sorrowful heart. He mentioned the "war of penance" [Buss-kampf] that characterized a true Christian. Through this war, they should eradicate all the rooted paganism from their hearts, stand up against sin, and enter the state of grace.

The last part of the sermon concerned the time of conversion. Ziegenbalg underlined that the conversion of the heathen had already happened, but it had not yet been fulfilled. ${ }^{86}$ In the Old Testament, conversion concerned only a few nonJews. In the New Testament, conversion had a much broader scope, according to

83 "Wie wir denn das kindliche Vertrauen zu Gott haben, daß er diese Jerusalems-Gemeine von Jahr zu Jahr durch seinen Segen aus den Heyden vermehren werde.” Ziegenbalg and Gründler, Achtzehende Continuation des Berichts, 295.

84 “[. . .] daß diejenige erfreuliche Harmonie, die zwischen Zion und Jerusalem gewesen, auch unter diesen beyden Gemeinen alhier sey; damit iederman erkenne, man wandle in einem Geiste und in einem Sinn, welche Einigkeit das kräftigste Mittel ist, das Reich des Satans zu zerstören und das Reich JESU CHRISTI anzurichten.” Ziegenbalg and Gründler, Achtzehende Continuation des Berichts, 296.

85 Ziegenbalg and Gründler, Achtzehende Continuation des Berichts, 300-01.

86 "Wir müssen also sagen, dass solche Bekehrung der Heyden theils schon geschehen sey, theils aber noch geschehen solle." Ziegenbalg and Gründler, Achtzehende Continuation des Berichts, 307. 


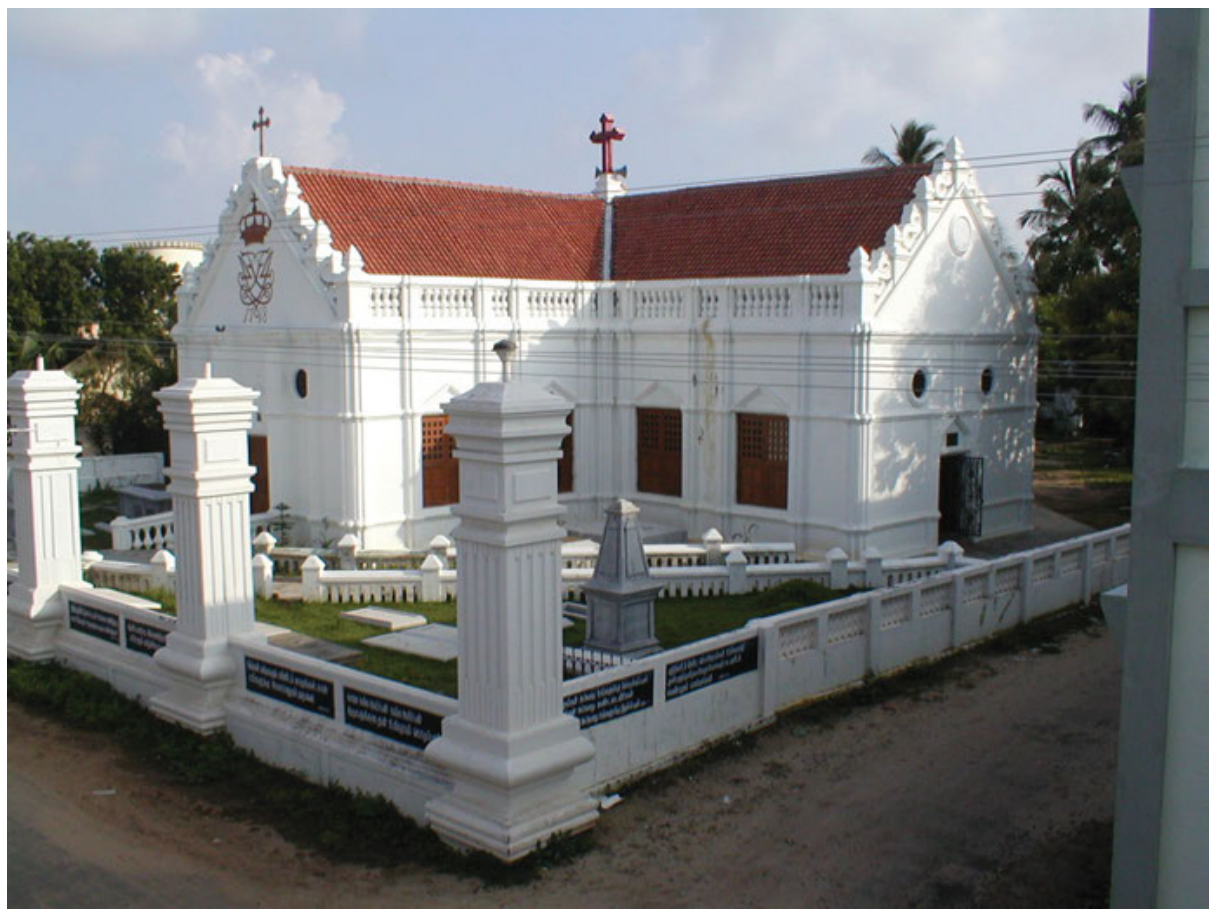

Fig. 21.4: The new Jerusalem Church, Tranquebar, India, with the monogram of King Christian VI of Denmark above the entrance. Erected Erected 1718, renovated 2006.

Ziegenbalg: a rich mercy, and a general call to "all the peoples.” The Apostles preached in Asia, and many people had the chance to hear the Gospel. However, it was long after the time of the Apostles until Germany, Denmark, Norway, and Sweden were converted from paganism to Christianity. Ziegenbalg's point was that such "conversion of the heathen" continued, because there were many heathen people in the world. The universal promise of all people praising God was thus both fulfilled and unfulfilled. Christians, whose forefathers had once converted, should not keep conversion for themselves, Ziegenbalg emphasized. ${ }^{87}$ The heathen must be given the chance to convert, and the church gave ample opportunity to do so.

Ziegenbalg concluded his sermon with thanks to King Frederick IV, whom he portrayed as an ideal Christian ruler. Through his mission initiative, the king had

87 “[. . .] dass wir es für eine hohe Wohlthat erkennen, dass unseren heydnischen Vorfahren die Gnaden-Mittel zu ihrer Bekehrung angetragen worden, müssen wir uns auch mit allem Fleiss dahin bemühen, wie durch uns auf einigerley Art und Weise den ietzigen Heyden zu ihrer Bekehrung Anlass und Gelegenheit gegeben werden möge.” Ziegenbalg and Gründler, Achtzehende Continuation des Berichts, 315. 
started a movement and prompted other people to do the same. ${ }^{88}$ Ziegenbalg was not afraid of exclamations: “Ah! Bless your New Jerusalem, may many children be born there," 89 before he extended prayers for blessings over the house of the king. He ended by praying that "all those gathered in the earthly Jerusalem" may one day be gathered in the heavenly Jerusalem, where "the host of the church triumphant will sing and praise with incessant rejoicing and exultation.” (Fig. 21.4). ${ }^{90}$

\section{Conclusion}

In this chapter, the New Jerusalem church in Tranquebar has been interpreted as a central sign for the first Lutheran mission activity. A main finding is its creative ambivalence: the kingdom of God is already at hand and simultaneously not yet fulfilled. In line with chiliastic expectations of the Pietists, the church could be seen as a realization of the promised city. At the same time, the remaining sinfulness and external structure pointed in another direction.

88 "[. . .] dass du hier und da in Europa unter Hohen und Niedrigen viele Wohlthäter erwecket, die durch ihre Mildthätigkeit, durch Gebet, Rath und That, dem hiesigen Bekehrungs-Werk die Hand gereicht haben.” Ziegenbalg and Gründler, Achtzehende Continuation des Berichts, 317.

89 "Ach! segne dieses dein Neu-Jerusalem, und lass dir viele Kinder darin gebohren werden!" Ziegenbalg and Gründler, Achtzehende Continuation des Berichts.

90 Ziegenbalg and Gründler, Achtzehende Continuation des Berichts, 320. 